\title{
Characterization of the Resistance of Alloy 22 to Stress Corrosion Cracking
}

\author{
K.J. King, J.C. Estill, R.B. Rebak
}

This article was submitted to

American Society of Mechanical Engineers Pressure Vessels and Piping Conference, Vancouver, Canada, August 4-8, 2002

\section{May 30, 2002}

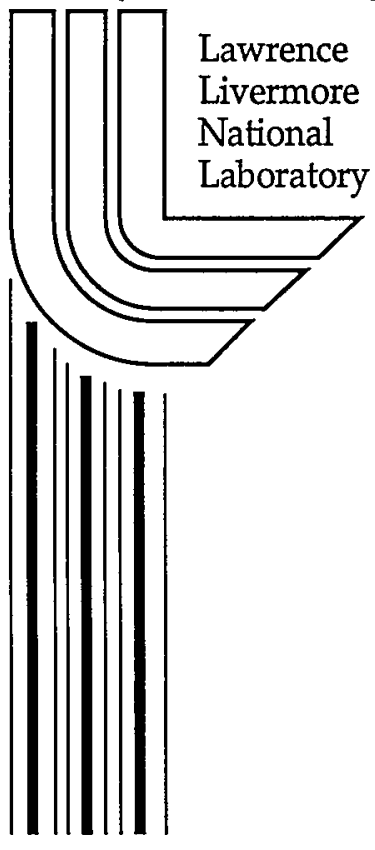




\section{DISCLAIMER}

This document was prepared as an account of work sponsored by an agency of the United States Government. Neither the United States Government nor the University of California nor any of their employees, makes any warranty, express or implied, or assumes any legal liability or responsibility for the accuracy, completeness, or usefulness of any information, apparatus, product, or process disclosed, or represents that its use would not infringe privately owned rights. Reference herein to any specific commercial product, process, or service by trade name, trademark, manufacturer, or otherwise, does not necessarily constitute or imply its endorsement, recommendation, or favoring by the United States Government or the University of California. The views and opinions of authors expressed herein do not necessarily state or reflect those of the United States Government or the University of California, and shall not be used for advertising or product endorsement purposes.

This is a preprint of a paper intended for publication in a journal or proceedings. Since changes may be made before publication, this preprint is made available with the understanding that it will not be cited or reproduced without the permission of the author.

This report has been reproduced directly from the best available copy.

Available electronically at http://www.doc.gov/bridge

Available for a processing fee to U.S. Department of Energy

And its contractors in paper from

U.S. Department of Energy

Office of Scientific and Technical Information

P.O. Box 62

Oak Ridge, TN 37831-0062

Telephone: (865) 576-8401

Facsimile: (865) 576-5728

E-mail: reports@adonis.osti.gov

Available for the sale to the public from

U.S. Department of Commerce

National Technical Information Service

5285 Port Royal Road

Springfield, VA 22161

Telephone: (800) 553-6847

Facsimile: (703) 605-6900

E-mail: orders@ntis.fedworld.gov

Online ordering: http://www.ntis.gov/ordering.htm

OR

Lawrence Livermore National Laboratory

Technical Information Department's Digital Library

http://www.llnl.gov/tid/Library.html 
Paper 03E-02 to be presented at the 2002 ASME Pressure Vessels and Piping Conference in Vancouver (Canada), August 4-8, 2002

\title{
CHARACTERIZATION OF THE RESISTANCE OF ALLOY 22 TO STRESS CORROSION CRACKING
}

\author{
Kenneth J. King, John C. Estill and Raúl B. Rebak \\ Lawrence Livermore National Laboratory, Livermore, CA, 94550
}

\begin{abstract}
In its current design, the high-level nuclear waste containers include an external layer of Alloy 22 (Ni-22Cr-13Mo-3W-3Fe). Since over their lifetime, the containers may be exposed to multi-ionic aqueous environments, a potential degradation mode of the outer layer could be environmentally assisted cracking (EAC). The objective of the current research was to characterize the effect of applied potential and temperature on the susceptibility of Alloy 22 to EAC in simulated concentrated water (SCW) using the slow strain rate test (SSRT). Results show that Alloy 22 may suffer EAC at applied potentials approximately $400 \mathrm{mV}$ more anodic than the corrosion potential $\left(E_{\text {cor }}\right)$.
\end{abstract}

Keywords: nuclear waste container, N06022, environmentally assisted cracking (EAC), slow strain rate test, applied potential, simulated concentrated water (SCW).

\section{INTRODUCTION}

The current design concept for the high-level nuclear waste containers in the USA is based on a metallic multi-barrier system. This design specifies a 2-cm thick external layer of Alloy 22 (UNS N06022) and a 5-cm thick internal layer of type 316 stainless steel (UNS S31603). ${ }^{\prime}$ Alloy 22 is a nickel $(\mathrm{Ni})$ based alloy that contains approximately $22 \%$ chromium $(\mathrm{Cr}), 13 \%$ molybdenum (Mo), 3\% tungsten (W) and 3\% iron (Fe). The main purpose of the internal barrier is to provide structural integrity and to contribute to the shielding of radiation. The main role of the external barrier is to provide protection against corrosion. Alloy 22 was selected for the external barrier due to its excellent resistance to general corrosion, localized corrosion and environmentally assisted cracking in a broad range of environments. ${ }^{1-6}$ If water is present during the emplacement time of the containers, three types of corrosion may occur. These are: (1) Uniform or passive corrosion, (2) Localized corrosion such as crevice corrosion and (3) Environmentally assisted cracking (EAC) such as stress corrosion cracking (SCC). This paper deals only with the behavior of Alloy 22 regarding EAC or SCC.

Mill annealed Alloy 22 is highly resistant to SCC in acidic concentrated chloride solutions. ${ }^{7-11}$ Dunn et al. did not find SCC when they tested Alloy 22 in 14 molal $\mathrm{Cl}^{-}$(as $\mathrm{MgCl}_{2}$ ) at $110^{\circ} \mathrm{C}$ and 
9.1 molal $\mathrm{LiCl}$ at $95^{\circ} \mathrm{C}$ under controlled potential. ${ }^{7-9}$ They used wedge opening loaded double cantilever beam (DCB) and compact tension (CT) specimens at stress intensities in the range 32 to $47 \mathrm{MPa} . \mathrm{m}^{1 / 2}$ for times as long a 52 weeks. ${ }^{7-9}$ Rebak reported that Alloy 22 U-bend specimens did not suffer SCC when exposed to $45 \% \mathrm{MgCl}_{2}$ at $154^{\circ} \mathrm{C}$ for up to 6 weeks. ${ }^{10}$ Estill et al. performed SSRT at a $1.6 \times 10^{-6} \mathrm{~s}^{-1}$ strain rate at the corrosion potential $\left(E_{\text {corn }}\right)$ in $4 \mathrm{M} \mathrm{NaCl}$ at $98^{\circ} \mathrm{C}$, saturated $\mathrm{CaCl}_{2}\left(>10 \mathrm{M} \mathrm{Cl}^{-}\right)$at $120^{\circ} \mathrm{C}$ and $1 \% \mathrm{PbCl}_{2}$ at $95^{\circ} \mathrm{C} .{ }^{11}$ None of these specimens showed a loss of ductility or secondary cracking. "

Even though Alloy 22 is resistant to SCC in concentrated chloride solutions, it may be susceptible under other severe environmental conditions. ${ }^{12-15}$ Andresen et al. tested the susceptibility of Alloy 22 to $E A C$ at the corrosion potential $\left(E_{\text {corr }}\right)$ in basic saturated water $(B S W)$ at $110^{\circ} \mathrm{C} .^{12}$ This BSW multi-ionic solution is a version of concentrated solutions that might be obtained after evaporative tests of Yucca Mountain ground waters. ${ }^{16}$ Using the reversing DC potential drop technique, Andresen et al. reported a crack grow rate of $5 \times 10^{-13} \mathrm{~m} / \mathrm{s}$ in a $20 \%$ cold-worked specimen loaded to a stress intensity of $30 \mathrm{MPa} \cdot \mathrm{m}^{1 / 2}$. This EAC testing was carried out in air saturated BSW water of $\mathrm{pH} \sim 13$. The testing conditions used by Andresen et al. were highly aggressive and, in spite of that, the measured crack growth rate was near the detection limit of the system. ${ }^{12}$ Rebak et al. reported that Alloy 22 U-bend specimens suffered transgranular SCC when they were exposed for $336 \mathrm{~h}$ to aqueous solutions of $20 \% \mathrm{HF}$ at $93^{\circ} \mathrm{C}$ and to its corresponding vapor phase. ${ }^{13}$ The liquid phase was more aggressive than the vapor phase. ${ }^{13}$ Pulvirenti et al. reported transgranular cracking in one out of four Alloy $22 \mathrm{U}$-bend specimen exposed for 15 days at $250^{\circ} \mathrm{C}$ in concentrated ground water contaminated with $0.5 \%$ lead $(\mathrm{Pb})$ and acidified to $\mathrm{pH} 0.5{ }^{14-15}$ Estill et al. performed slow strain rate tests, cyclic loading tests and U-bend tests in large variety of environments (temperature, applied potential and solution composition). ${ }^{15}$ They only reported SCC on MA Alloy 22 through SSRT in saturated concentrated water (SCW) at $73^{\circ} \mathrm{C}$ and at a potential of $+0.4 \mathrm{~V}$ [SSC]. ${ }^{\prime \prime}$

The purpose of the present work was use SSRT to explore the influence of applied potential and temperature on the susceptibility of Alloy 22 to suffer SCC in SCW.

\section{EXPERIMENTAL TECHNIQUE}

The SSRT specimens were machined from wrought mill annealed plate stock (Heat 2277-83126). The chemical composition of the alloy in weight percent was: $\sim 57 \% \mathrm{Ni}, 21.7 \% \mathrm{Cr}$, $13.26 \% \mathrm{Mo}, 2.8 \% \mathrm{~W}, 3.59 \% \mathrm{Fe}, 1.03 \% \mathrm{Co}, 0.27 \% \mathrm{Mn}, 0.14 \% \mathrm{~V}, 0.004 \% \mathrm{C}$ and $0.001 \% \mathrm{~S}$. The typical mechanical properties of $\mathrm{MA}$ plate material are listed in Table 1 . The specimens were tested in the as-machined condition, which corresponded to a root mean square (RMS) roughness of $32 \mu$-inch. The specimens were degreased in acetone before testing. Each specimen was cylindrical, approximately 7.25 -inch $(184 \mathrm{~mm})$ long and 0.438 -inch $(11 \mathrm{~mm})$ diameter. The useful gage of the specimens was 1 -inch $(25.4 \mathrm{~mm})$ long and had a 0.1 -inch $(2.54 \mathrm{~mm})$ diameter. Only the useful gage section was exposed to the electrolyte solution. Other areas of the specimens were covered with a protective coating. The slow strain rate tests were conducted at a constant deformation rate of $1.6 \times 10^{-6} \mathrm{~s}^{-1}$. 
Tests were carried in simulated concentrated water (SCW), which is a complex electrolyte simulating an environment that would be obtained after reducing the volume of ground water from the Yucca Mountain site approximately 1000 times through evaporation. The used composition of SCW in $\mathrm{mg} / \mathrm{L}$ was: 3,400 potassium $(\mathrm{K}), 40,900$ sodium $(\mathrm{Na}), 1,400$ fluorine $(\mathrm{F}), 6,700$ chlorine (Cl). 6,400 nitrate $\left(\mathrm{NO}_{3}{ }^{-}\right), 16,700$ sulfate $\left(\mathrm{SO}_{4}{ }^{2}\right), 70,000$ bicarbonate $\left(\mathrm{HCO}_{3}{ }^{-}\right)$and approximately 40 silicon ( $\mathrm{Si}$ ). The $\mathrm{pH}$ of this solution is generally between 9 to 10 . The electrolyte solution was naturally aerated; that is, a stream of air was circulated above the level of the electrolyte solution. All tests were carried out under ambient pressure under applied potential. The electrochemical potentials in this paper are reported in the saturated silver-silver chloride scale [SSC]. At ambient temperature, the SSC scale is $197 \mathrm{mV}$ more positive than the normal hydrogen electrode (NHE). After testing, the samples were evaluated using optical and scanning electron microscopy (SEM).

\section{EXPERIMENTAL RESULTS AND DISCUSSION}

Table 2 shows the experimental results. Two specimens were strained to rupture in air as reference tests for inert environments. Table 2 shows the testing conditions such as testing temperature, applied potential and $E_{\text {corr }}$ of the specimens in the solution before the tests. The average $E_{\text {corr }}$ of all the specimens (Table 2) before starting the applied potential was approximately $-0.15 \mathrm{~V}$ [SSC]. Table 2 also shows the results from the tests such as the maximum stress reached during straining, the time to failure and the reduction in area of the specimens at the time of failure. The susceptibility to stress corrosion cracking in the aqueous environment can be assessed by comparing these three parameters with the same parameters in air.

Figure 1 shows the time to failure of the strained specimens as a function of the applied potential. Two data for specimens strained in air at room temperature are also included. Figure 1 shows that the higher the applied potential the lower the time to failure. The lowest time to failure was obtained for the specimens strained at $+0.4 \mathrm{~V}$ [SSC]. Figure 2 is an SEM image of the fracture end of a specimen strained in air. This shows typical ductile failure with necking before cracking. Figure 3 shows a SEM low magnification image of a specimen strained in SCW at $+0.1 \mathrm{~V}$ [SSC] and Figure 4 is a larger magnification of the lateral surface of the same specimen. Alloy 22 was not susceptible to cracking at $+0.1 \mathrm{~V}$ [SSC] since the specimen showed considerably necking before failure (Figure 2 and 3 ) and the lateral surface was free of secondary cracking (Figure 4). Figures 5-6 show the characteristics of a specimen strained in SCW at $+0.2 \mathrm{~V}$ [SSC]. Figure 5 shows considerable necking before failure; however, Figure 6 shows incipient secondary cracking in the lateral surface. Specimen 029 (Table 2), which was also strained at $+0.2 \mathrm{~V}$ [SSC] but at higher temperature, seemed to show deeper secondary fissures than the specimen strained at $73^{\circ} \mathrm{C}$ (Figures 5 and 6). Figure 7 is a low magnification SEM image of a specimen strained in $\mathrm{SCW}$ at $+0.4 \mathrm{~V}$ [SSC] showing that the failure of this specimen occurred with little reduction in area (necking). Figure 7 also shows that there is abundant secondary cracking in the lateral surface. Figure 8 is an SEM image of the fracture surface showing that the environmentally induced cracking was transgranular in nature. Figure 9 is a metallographic cross section of the same specimen showing that the EAC cracks are shallow and open, probably because the strain rate was high; not allowing enough time crack propagation. 
Figure 10 shows the stress-elongation curves for Alloy 22 specimens strained at $0.4 \mathrm{~V}$ in three different electrolyte solutions. (A similar graph was published before ${ }^{11}$ ). Figure 10 shows that Alloy 22 was susceptible to EAC in SCW solution at $73^{\circ} \mathrm{C}$ but was not susceptible to EAC in basic saturated water (BSW) pH 12 at $105^{\circ} \mathrm{C}$ or simulated saturated water (SSW) pH 6.7 at $100^{\circ} \mathrm{C}$. Table 2 shows that when Alloy 22 was strained in SCW at $+0.4 \mathrm{~V}$ [SSC] at ambient temperature $\left(25^{\circ} \mathrm{C}\right)$, the parameters time to failure, ultimate tensile strength and reduction in area were similar to the same parameters for the specimens strained in air. Observations from Table 2 and Figures 1-10 show that the susceptibility of Alloy 22 to EAC is highly sensitive to environmental conditions such as temperature, electrolyte composition and applied potential.

Figure 11 shows the polarization curve for MA Alloy 22 in SCW at $90^{\circ} \mathrm{C}$. There is an anodic peak in the potential range between +0.2 to $+0.4 \mathrm{~V}$ [SSC]. The range of potential for cracking susceptibility of Alloy 22 seems to be associated to the presence of this anodic peak. For example, Table 2 shows that in SCW at ambient temperature and at $+0.4 \mathrm{~V}$ [SSC]; Alloy 22 failed in a ductile manner. The polarization curve of Alloy 22 in SCW at $25^{\circ} \mathrm{C}$ did not show the presence of the active peak. Currently, the windows of temperature and electrochemical potential for susceptibility of Alloy 22 to EAC are being explored further.

The results from this paper suggest that Alloy 22 might be susceptible to EAC in multi-ionic solutions that could be representative of concentrated Yucca Mountain underground water. However, current results also show that for MA Alloy 22 to fail by EAC in SCW solution, several conditions are required to be applied simultaneously: (1) A temperature higher than approximately $70^{\circ} \mathrm{C}$, (2) A stress level in the order of $600 \mathrm{MPa}$ (two times the level of the yield stress) and (3) Anodic potentials in the order of $+0.3 \mathrm{~V}$ [SSC]. Therefore, it is unlikely that the actual container would be susceptible to EAC even though it may enter in contact with a SCW type of solution at high temperature. Firstly, because in the design of the waste package it is predicted that the container will be fully annealed to eliminate any residual stress due to welding. Second, because data (Figure 12) shows that the $E_{\text {corr }}$ of Alloy 22 after more than 5 years immersion in aerated SCW at $90^{\circ} \mathrm{C}$ remained below $0 \mathrm{~V}$ [SSC], that is, at least $0.3 \mathrm{~V}$ below the range of potential susceptibility. Table 2 also shows that $E_{\text {corr }}$ for Alloy 22 in aerated SCW was also below $0 \mathrm{~V}$ [SSC].

\section{CONCLUSIONS}

(1) The susceptibility of MA Alloy 22 to EAC in SCW depended strongly on environmental conditions including the applied potential and testing temperature.

(2) Alloy 22 was susceptible to EAC in SCW at +0.3 and $+0.4 \mathrm{~V}$ [SSC] at temperatures 73$95^{\circ} \mathrm{C}$. However, EAC did not occur at $+0.4 \mathrm{~V}$ and $25^{\circ} \mathrm{C}$.

(3) Alloy was not susceptible to EAC in SCW at $73^{\circ} \mathrm{C}$ and $+0.1 \mathrm{~V}$ [SSC] applied potential and would probably be also resistant to cracking at $\mathrm{E}_{\text {corr }}$ (in the order of $-0.15 \mathrm{~V}$ [SSC]). 
(4) It is unlikely that Alloy 22 would suffer EAC under environmental conditions that could be encountered in Yucca Mountain since the stresses of the container will be relieved and because $E_{\text {cor }}$ of the alloy is expected to be below the potential range for susceptibility.

\section{ACKNOWLEDGMENTS}

The authors want to acknowledge the contributions by Gary A. Hust, James L. Ferreira and Steve R. Gordon. This work was performed under the auspices of the U. S. Department of Energy by the University of California Lawrence Livermore National Laboratory under contract $\mathrm{N}^{\circ} \mathrm{W}$ 7405-Eng-48. This work is supported by the Yucca Mountain Site Characterization Project, LLNL.

\section{DISCLAIMER}

This document was prepared as an account of work sponsored by an agency of the United States Government. Neither the United States Government nor the University of California nor any of their employees, makes any warranty, express or implied, or assumes any legal liability or responsibility for the accuracy, completeness, or usefulness of any information, apparatus, product, or process disclosed, or represents that its use would not infringe privately owned rights. Reference herein to any specific commercial product, process, or service by trade name, trademark, manufacturer, or otherwise, does not necessarily constitute or imply its endorsement, recommendation, or favoring by the United States Government or the University of California. The views and opinions of authors expressed herein do not necessarily state or reflect those of the United States Government or the University of California, and shall not be used for advertising or product endorsement purposes.

\section{REFERENCES}

1. D. S. Dunn, G. A. Cragnolino and N. Sridhar in Scientific Basis for Nuclear Waste Management XXIII, Materials Research Society, (Warrendale, PA 2000), pp. 89-94.

2. P. E. Manning, J. D. Schöbel, Werkstoffe und Korrosion, 37, 137-145 (1986).

3. S. J. Lukezich, "The Corrosion Behavior of Ni-Base High Performance Alloys in Simulated Repository Environments," MS Thesis, The Ohio State University, 1989.

4. K. A. Gruss, G. A. Cragnolino, D. S. Dunn, N. Sridhar, Paper 149, Corrosion/98, NACE International, (Houston, TX 1998).

5. R. B. Rebak and P. Crook, in Critical Factors in Localized Corrosion III, The Electrochemical Society, Volume 98-17, (Pennington, NJ 1999), pp. 289-302.

6. R. B. Rebak in Corrosion and Environmental Degradation, Volume II, Wiley-VCH (Weinheim, Germany 2000), pp. 69-111.

7. Y.-M. Pan, D. S. Dunn and G. A. Cragnolino in Environmentally Assisted Cracking: Predictive Methods for Risk Assessment and Evaluation of Materials, Equipment and Structures, ASTM STP 1401, (West Conshohocken, PA 2000), pp. 273-288. 
8. D. S. Dunn and C. S. Brosia, Paper 125, Corrosion/01, NACE International, (Houston, TX 2001).

9. D. S. Dunn, Y.-M. Pan and G. A. Cragnolino, Paper 425, Corrosion/02, NACE International, (Houston, TX 2002).

10. R. B. Rebak in Environmentally Assisted Cracking: Predictive Methods for Risk Assessment and Evaluation of Materials, Equipment and Structures, ASTM STP 1401, (West Conshohocken, PA 2000), pp. 289-300.

11. J. C. Estill, K. J. King, D. V. Fix, D. G. Spurlock, G. A. Hust, S. R. Gordon, R. D. McCright, G. M. Gordon and R. B. Rebak, Paper 535, Corrosion/02, NACE International, (Houston, TX 2002).

12. P. L. Andresen, P. W. Emigh, L. M. Young and G. M. Gordon, Paper 130, Corrosion/01, NACE International, (Houston, TX 2001).

13. R. B. Rebak, J. R. Dillman, P. Crook and C. V. V. Shawber, Materials and Corrosion, 52 (2001), pp. 289-297.

14. A. L. Pulvirenti, K. M. Needham, M. A. Adel-Hadadi, C. R. Marks, J. A. Gorman and A. Barkatt, Paper JJ11.6, MRS Meeting, Boston November 26-30, 2001 (In Press).

15. A. L. Pulvirenti, K. M. Needham, M. A. Adel-Hadadi, A. Barkatt, C. R. Marks and J. A. Gorman, Paper 551, Corrosion/02, NACE International, (Houston, TX 2002).

16. N. D. Rosenberg, G. E. Gdowski and K. G. Knauss, Applied Geochemistry, 16 (2001), pp. 1231-1240.

TABLE 1

TYPICAL MECHANICAL PROPERTIES OF PLATE AND SHEET ALLOY 22

\begin{tabular}{cccccc}
\hline Heat & $\begin{array}{c}\text { Tensile } \\
\text { Strength [UTS] } \\
(\mathrm{MPa})\end{array}$ & $\begin{array}{c}\text { Yield Stress } \\
{[0.2 \%](\mathrm{MPa})}\end{array}$ & $\begin{array}{c}\text { Elongation to } \\
\text { Rupture (\%) }\end{array}$ & $\begin{array}{c}\text { Hardness } \\
(\mathrm{RB})\end{array}$ & $\begin{array}{c}\text { ASTM } \\
\text { Grain } \\
\text { Size }\end{array}$ \\
\hline $\begin{array}{c}\text { Sheet }-2277- \\
8-3203\end{array}$ & 824 & 412 & 62 & 92 & 5.5 \\
$\begin{array}{c}\text { Plate }-2277-8- \\
3126\end{array}$ & 766 & 387 & 64.4 & 83 & 4 \\
\hline
\end{tabular}


TABLE 2

SLOW STRAIN RATE $\left(\sim 1.6 \times 10^{-6} \mathrm{~S}^{-1}\right)$ TESTING OF MA ALLOY $22 \mathrm{IN} \mathrm{SCW}$

\begin{tabular}{|c|c|c|c|c|c|c|c|}
\hline Sample & $\begin{array}{l}\text { Temp. } \\
\left({ }^{\circ} \mathrm{C}\right)\end{array}$ & $\begin{array}{c}\mathrm{E}_{\text {corr }} \\
(\mathrm{SSC})\end{array}$ & $\begin{array}{l}\mathrm{E}_{\text {applied }} \\
\text { (SSC) }\end{array}$ & $\begin{array}{c}\text { Time to } \\
\text { Failure (h) }\end{array}$ & $\begin{array}{l}\text { UTS } \\
(\mathrm{ksi})\end{array}$ & $\begin{array}{l}\mathrm{RA} \\
(\%)\end{array}$ & $\begin{array}{c}\text { Observations } \\
\text { Stereomicroscope } \\
\text { X } 40 \text { and X100 }\end{array}$ \\
\hline 012 (Air) & $\overline{22}$ & $\overline{\mathrm{NA}}$ & $\overline{\mathrm{NA}}$ & 124 & 114 & 74 & Ductile, Necking \\
\hline 040 (Air) & 22 & NA & $\mathrm{NA}$ & 123 & 118 & 70 & Ductile, Necking \\
\hline 026 & 73 & -241 & +100 & 120 & 111 & 79 & $\begin{array}{l}\text { Ductile Failure, neck- } \\
\text { ing. No SCC }\end{array}$ \\
\hline 023 & 73 & -224 & +200 & NA & NA & 72 & $\begin{array}{l}\text { Necking. Incipient or } \\
\text { Shallow SCC }\end{array}$ \\
\hline 025 & 73 & -172 & +200 & 116 & $\mathrm{NA}$ & 80 & $\begin{array}{l}\text { Necking. Incipient or } \\
\text { Shallow SCC }\end{array}$ \\
\hline 029 & 88.5 & -144 & +200 & 112 & $\mathrm{NA}$ & 73 & $\begin{array}{l}\text { Necking. Incipient or } \\
\text { Shallow SCC }\end{array}$ \\
\hline 030 & 73 & -182 & +300 & 98 & NA & 65 & $\mathrm{SCC}$ \\
\hline 021 & 73 & -171 & +400 & 90 & 96 & 64 & SCC \\
\hline 112 & 95 & -94 & +400 & 91 & 101 & 71 & SCC \\
\hline 033 & 86 & -169 & +400 & 76 & NA & 44 & $\mathrm{SCC}$ \\
\hline 020 & 25 & -109 & +400 & 116 & 114 & 85 & $\begin{array}{l}\text { Ductile Failure, neck- } \\
\text { ing. No SCC }\end{array}$ \\
\hline
\end{tabular}

RA: Reduction in area at time of rupture, NA $=$ Not Applicable or Not Available

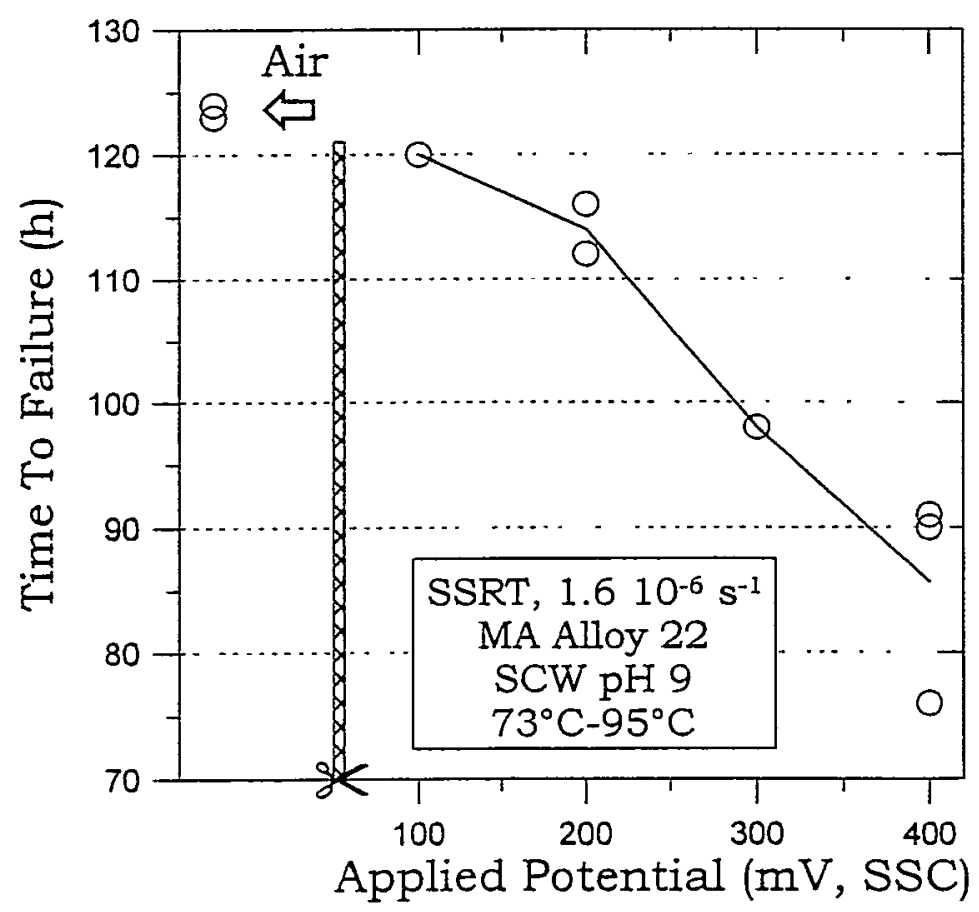

FIGURE 1: Effect of Potential on the time to failure of Alloy 22 in SCW. 


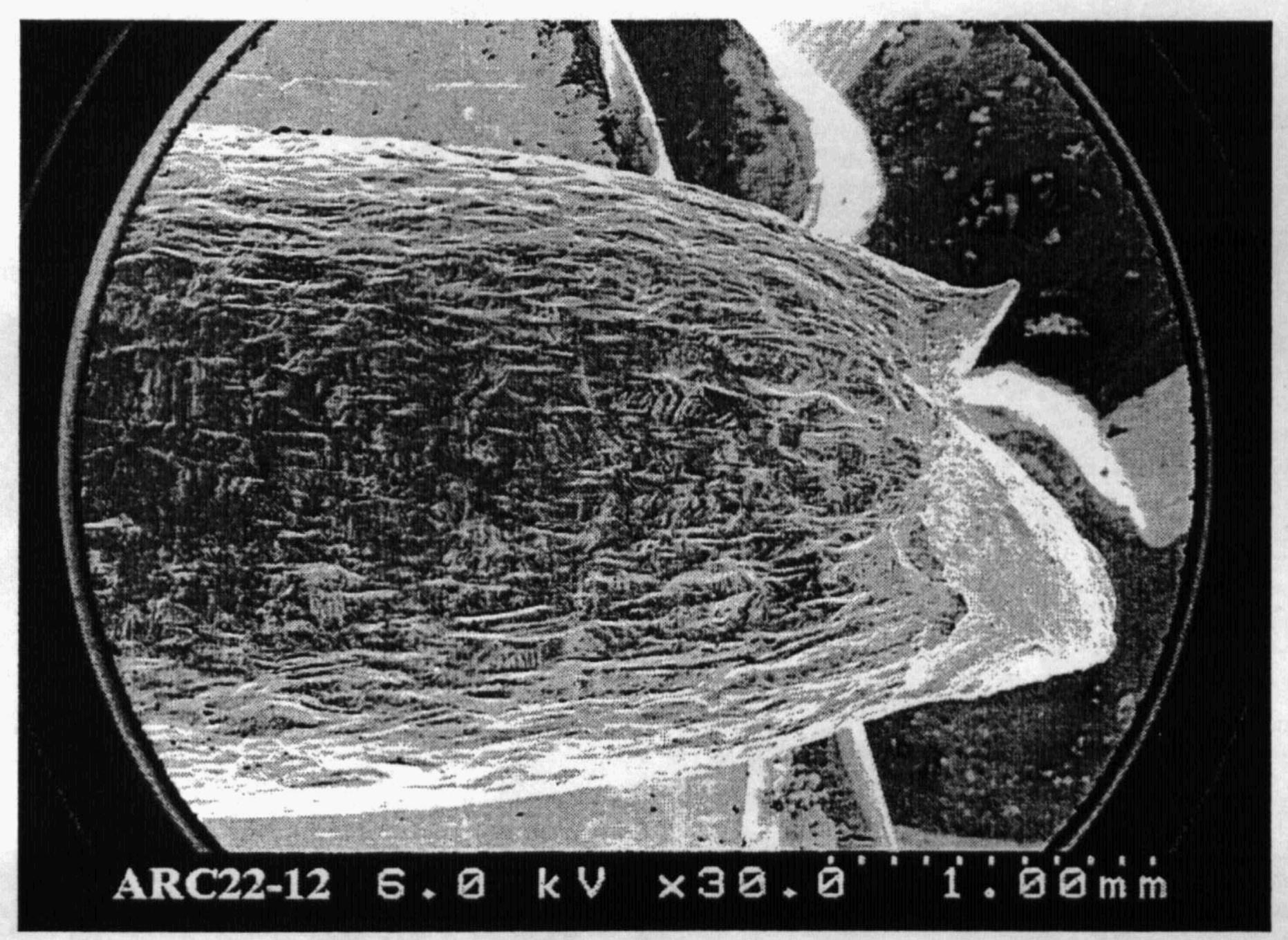

FIGURE 2: Fracture end of specimen strained in air at ambient temperature. Magnification X 30 .

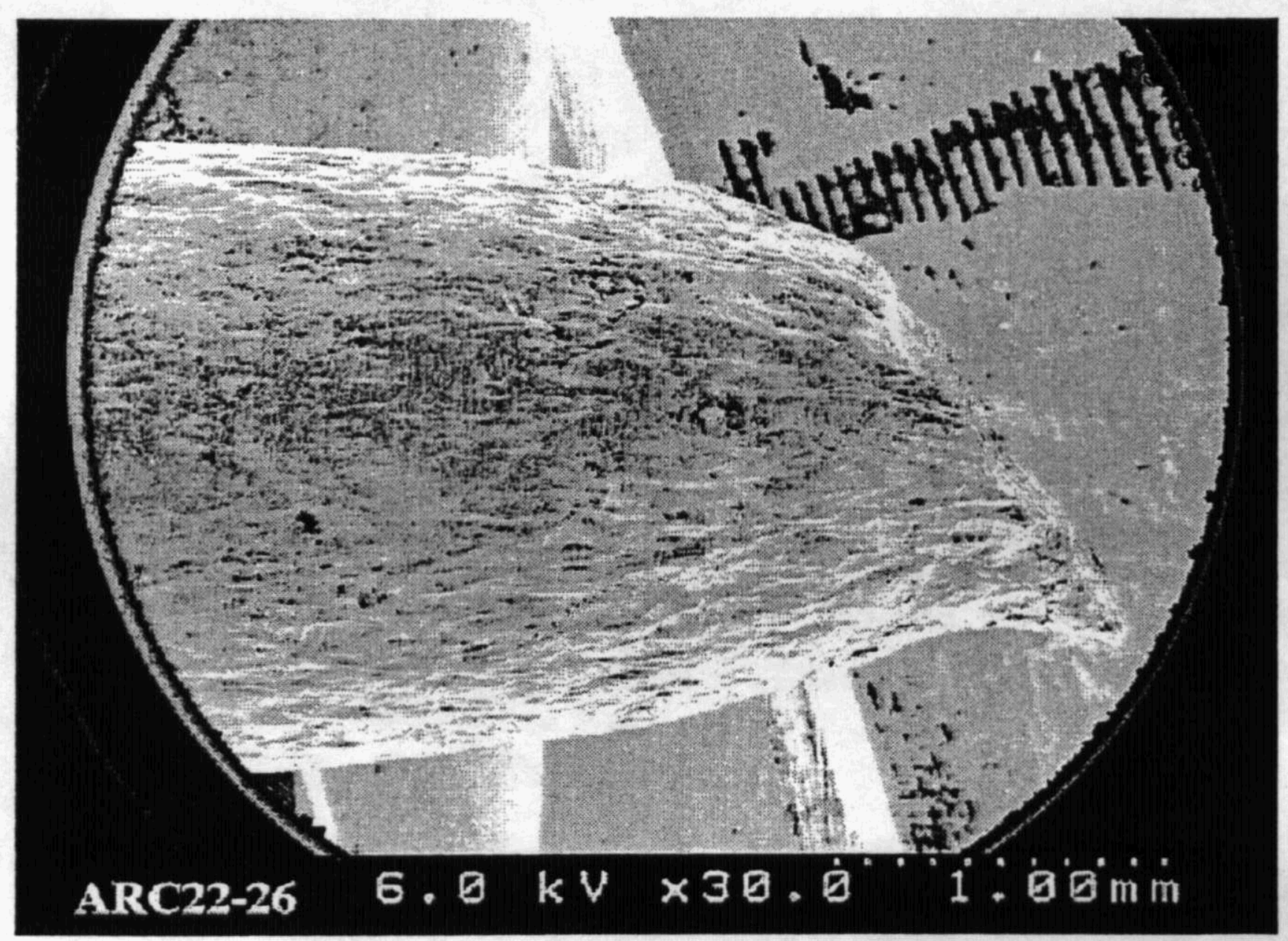

FIGURE 3: Fracture end of specimen strained in SCW at $73^{\circ} \mathrm{C}$ and $+0.1 \mathrm{~V}$. Magnification X 30. 


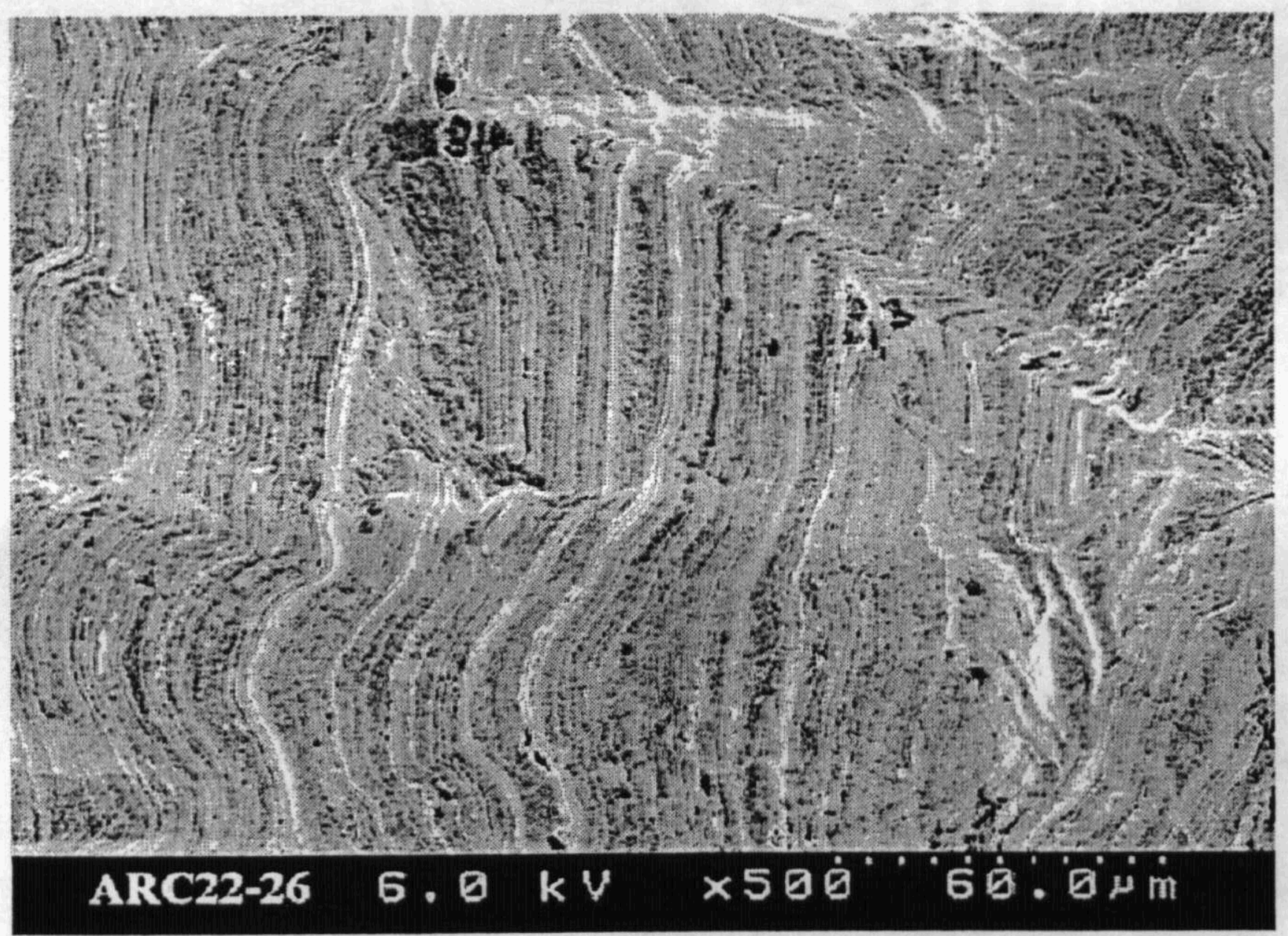

FIGURE 4: Fracture end of specimen strained in SCW at $73^{\circ} \mathrm{C}$ and $+0.1 \mathrm{~V}$. Magnification X 500 .

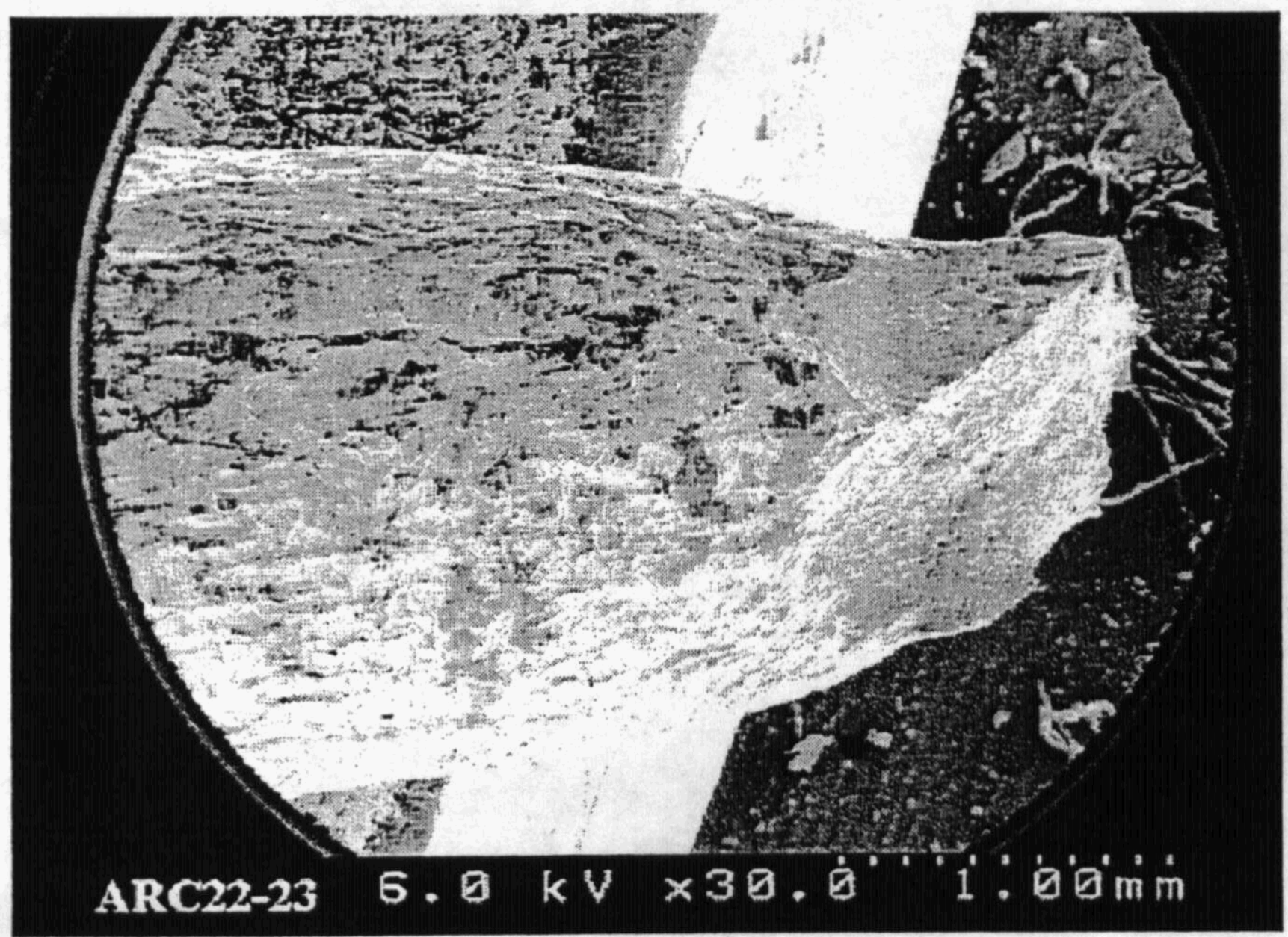

FIGURE 5: Fracture end of specimen strained in SCW at $73^{\circ} \mathrm{C}$ and $+0.2 \mathrm{~V}$. Magnification X 30 . 


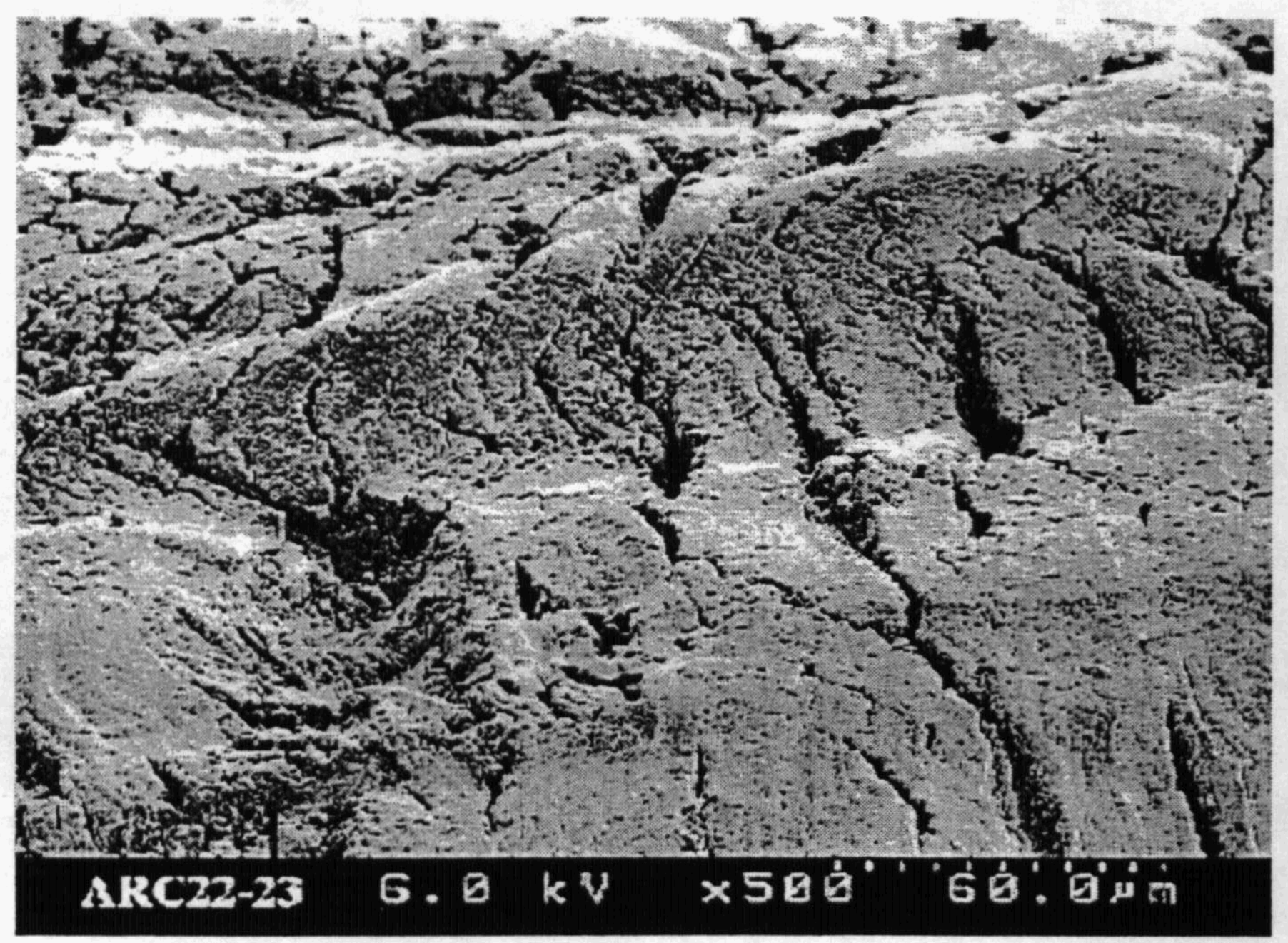

FIGURE 6: Fracture end of specimen strained in SCW at $73^{\circ} \mathrm{C}$ and $+0.2 \mathrm{~V}$. Magnification X 500.

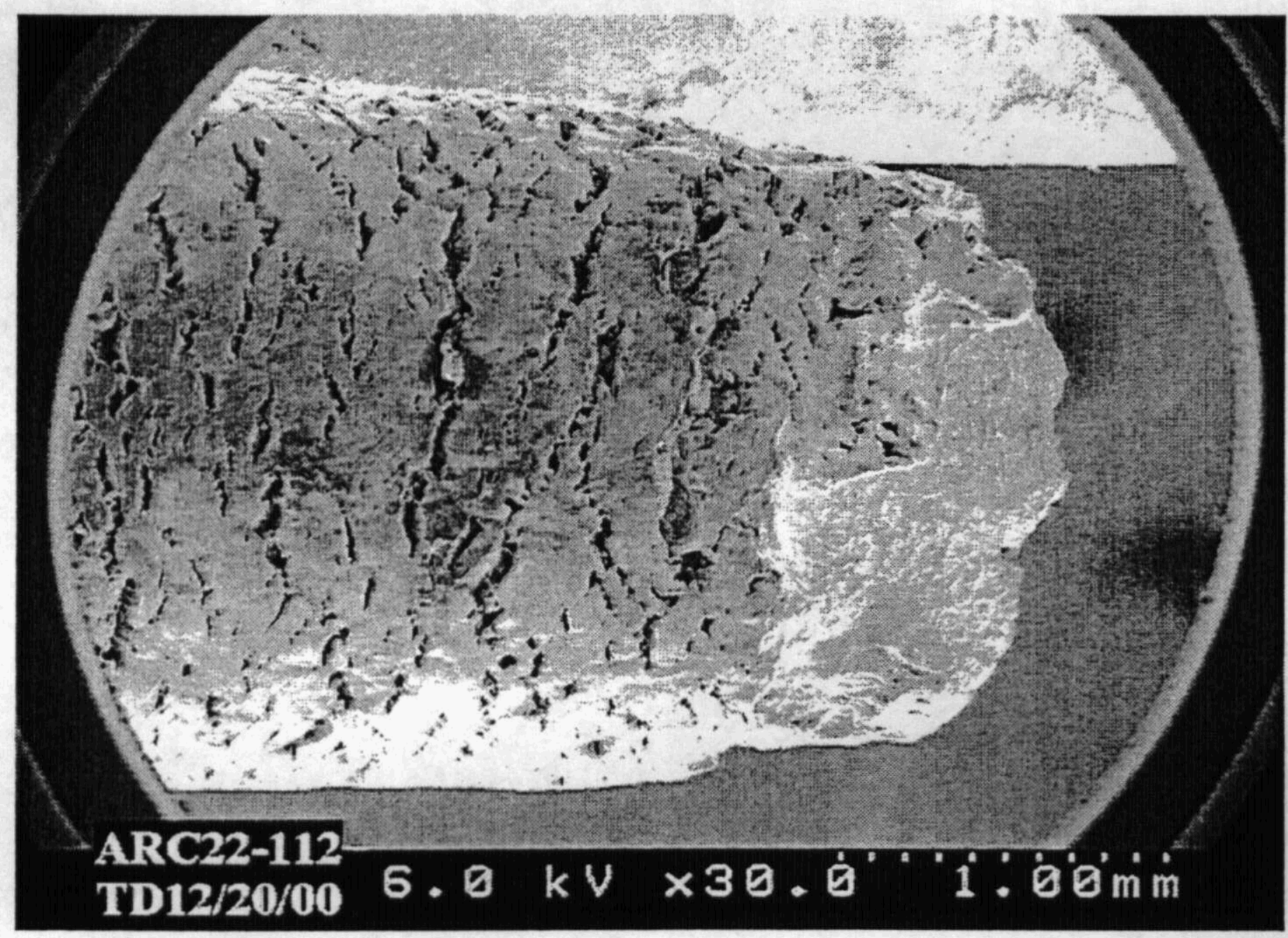

FIGURE 7: Fracture end of specimen strained in SCW at $73^{\circ} \mathrm{C}$ and $+0.4 \mathrm{~V}$. Magnification X 30 . 


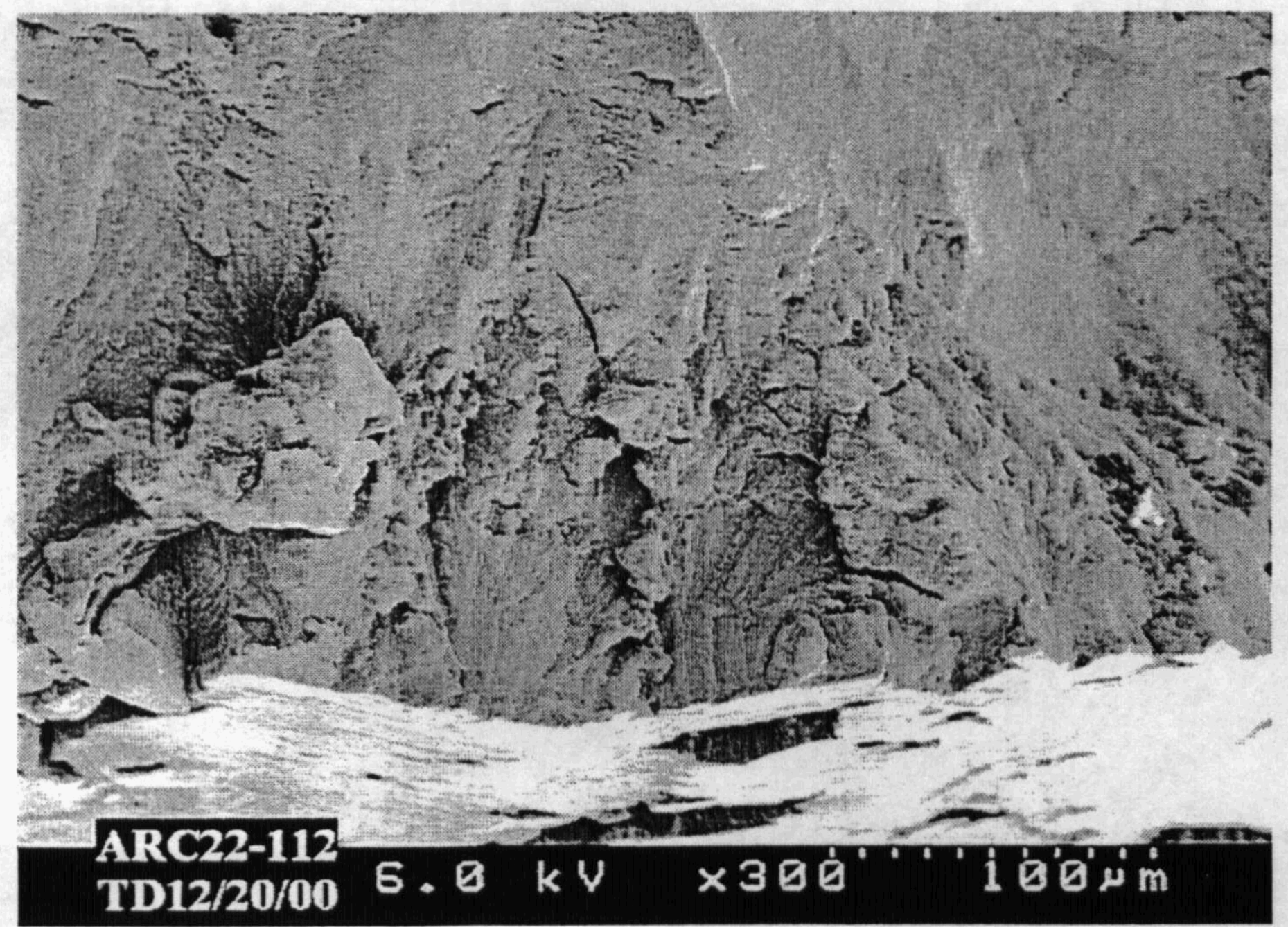

FIGURE 8: Fracture surface of specimen strained in $\mathrm{SCW}$ at $73^{\circ} \mathrm{C}$ and $+0.4 \mathrm{~V}$. Magnification X 300 .

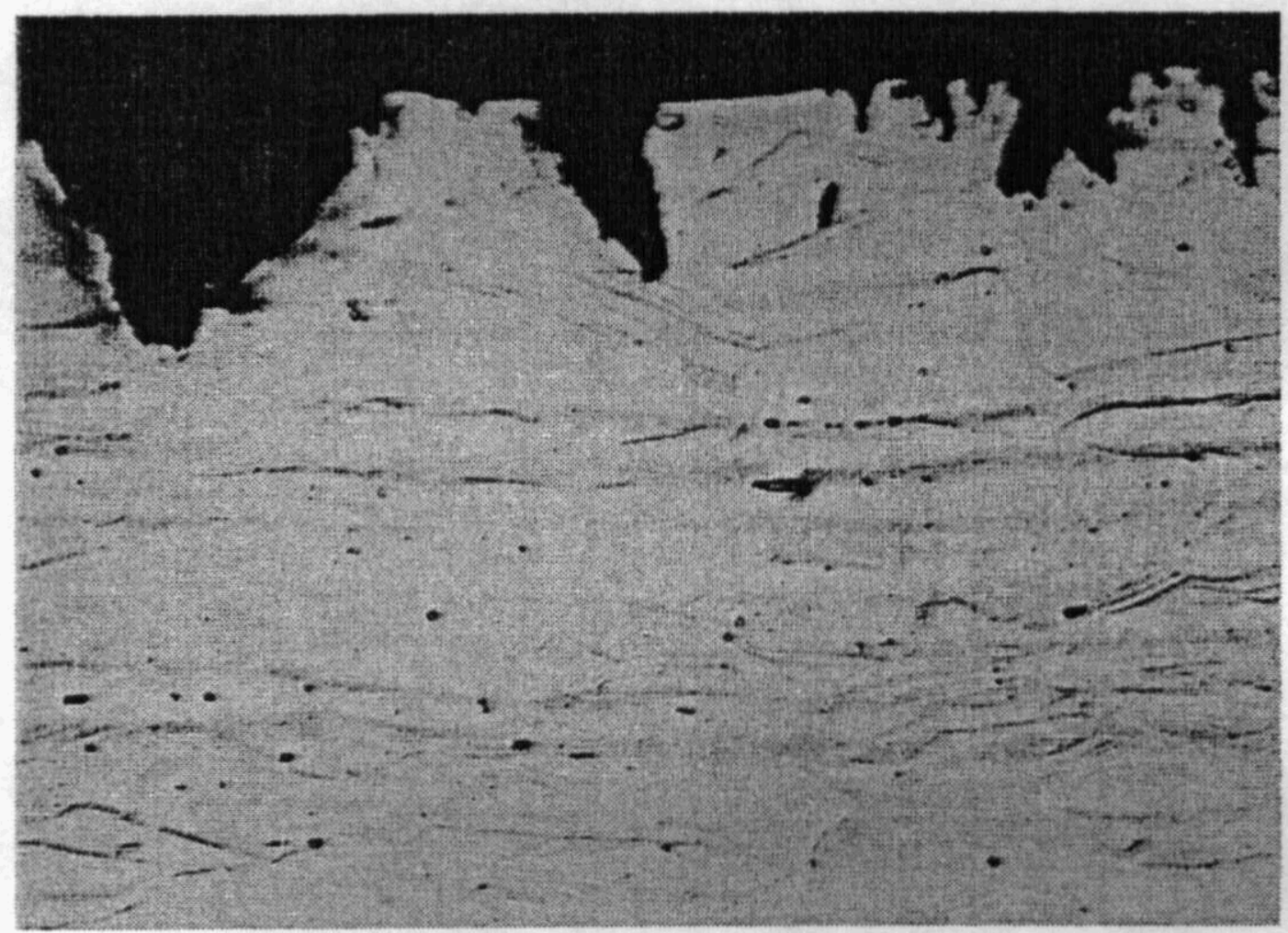

FIGURE 9: Metallographic sectioning of Alloy 22 (112) strained in SCW at $73^{\circ} \mathrm{C}$ and $+0.4 \mathrm{~V}$. Magnification X 200. 


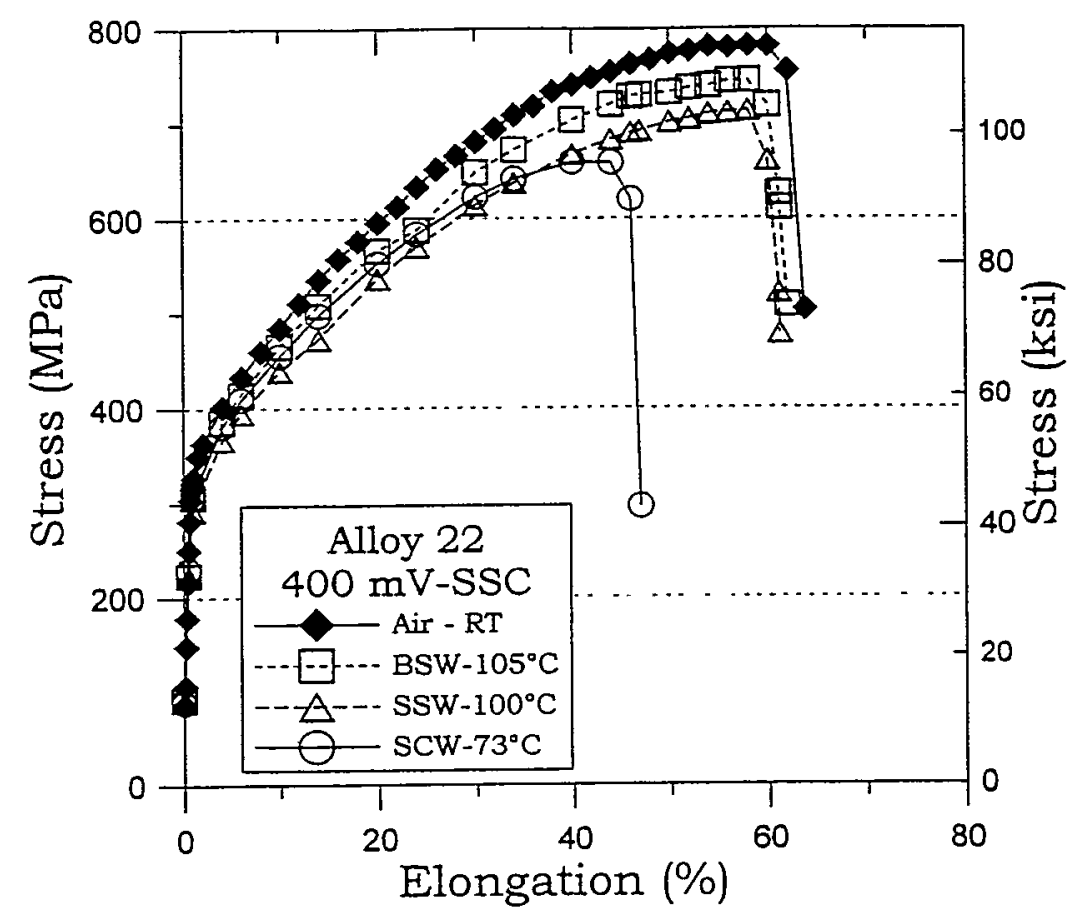

FIGURE 10: Stress-Elongation curves for Alloy 22 specimens strained at $+0.4 \mathrm{~V}$.

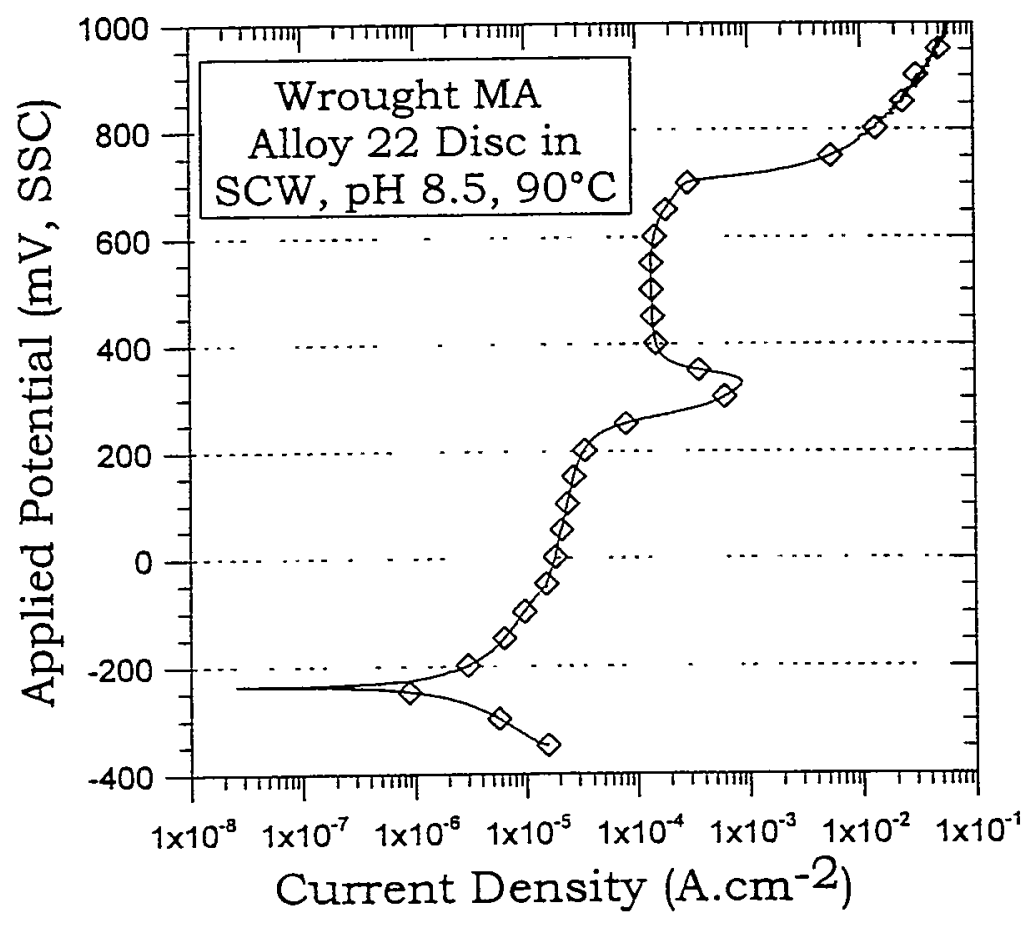

FIGURE 11: Polarization Curve for MA Alloy 22 in SCW at $90^{\circ} \mathrm{C}$. 


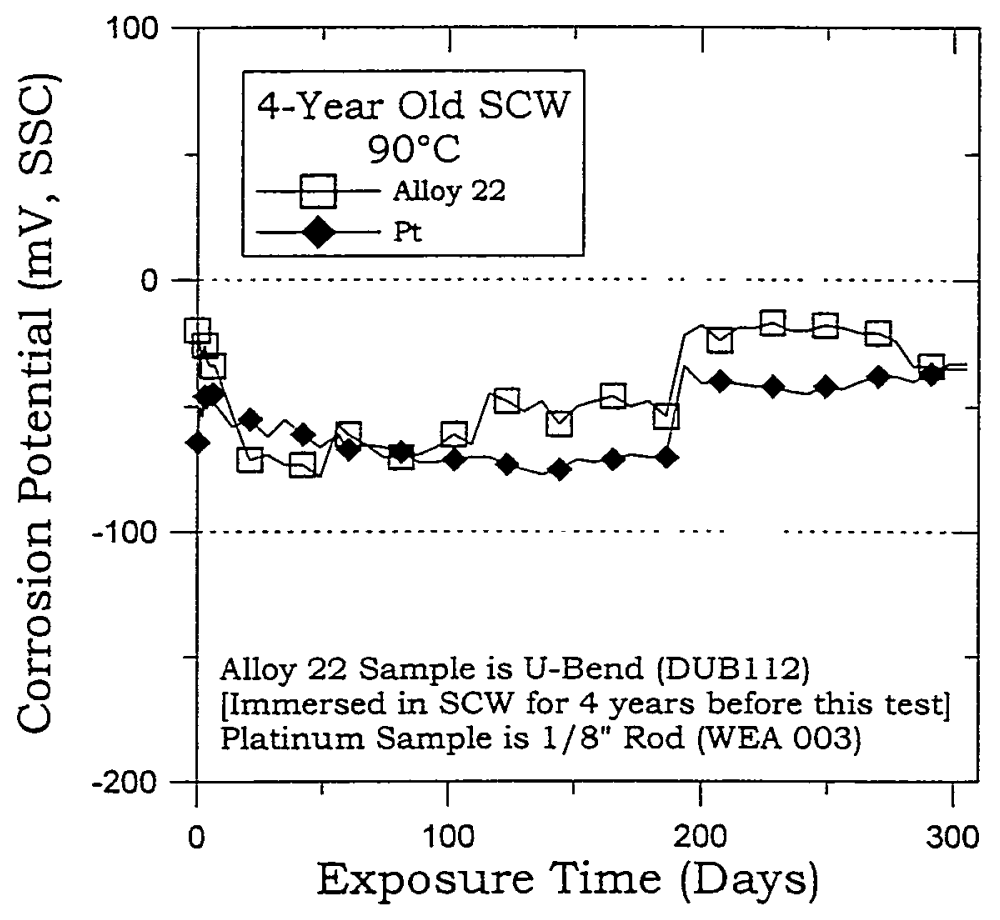

FIGURE 12: Corrosion Potential of Alloy 22 and Platinum in 4-year old SCW solution (from the Long Term Corrosion Test Facility). 